\title{
単孔式腹臆鏡下胆囊摘出術の検討
}

\author{
大塚眞哉*, 稲垣 優, 磯田健 太, 北田浩二, \\ 濱野亮輔, 西江 学, 徳永尚之, 常光洋輔, \\ 岩川和秀, 岩垣博已
}

国立病院機構福山医療センター 外科

\section{Clinical study of single-incision laparoscopic cholecystectomy}

\author{
Shinya Otsuka *, Masaru Inagaki, Kenta Isoda, Kouji Kitada, \\ Ryousuke Hamano, Manabu Nishie, Naoyuki Tokunaga, Yousuke Tsunemitsu, \\ Kazuhide Iwakawa, Hiromi Iwagaki
}

Department of Surgery, National Hospital Organization Fukuyama Medical Center, Hiroshima 720-8520, Japan

\begin{abstract}
We experienced 63 patients with non-inflammatory disease who underwent single-incision laparoscopic cholecystectomy (TANKO-LC). Herein we report the procedure of operation and the short-term results. We compared 63 cases of TANKO-LC with 109 cases of non-inflammatory conventional laparoscopic cholecystectomy (S-LC) within the same period. At first, our standard procedure was to insert multiple trocars in the abdominal cavity through a single wound; now, we insert only a single trocar all cases. In the 63 cases investigation, 3 cases required trocar addition and one case converted to open surgery. Intra and postoperative complications were recognized in 2 cases (port-site infection). No significant complications were recognized. In comparing the TANKO-LC group and the S-LC group, the operation time was intentionally longer in the TANKO-LC group (TANKO-LC group : 118 min, S-LC group : $90 \mathrm{~min}$ ), but there were no differences in the blood loss, the rates of intra and postoperative complications and the conversion rate. Laparoscopic cholecystectomy is a standard operation for gallbladder removal, but single-incision laparoscopic cholecystectomy is considered a useful operation with the same low operative complication rate yet more satisfactory cosmetic results.
\end{abstract}

キーワード：腹腔鏡下胆襄摘出術（laparoscopic cholecystectomy)，単孔式 (single-incision)

\section{緒言}

腹腔鏡下胆襄摘出術（以下 LC）は低侵襲と簡便性から 一般術式として普及している。通常は $3 \sim 4$ カ所のポート を挿入して手術を施行するが，1997年米国にて発表された 単孔式腹腔鏡下手術は11)，単孔あるいは単創式と言われる 臍部 1 所の創部から行う整容性に優れた術式であり, 本 邦でも胆囊摘出に導入されて以来様々な臓器に応用され, 良好な成績をあげている，当院でも2010年 2 月に導入して 2012年 8 月までに63例経験し, 良好な成績をあげており, 手術方法及び成績について報告する。

\section{対象と方法}

\section{単孔式腹腔鏡下胆囊摘出術（以下 TANKO-LC）は従来}

\section{平成 25 年 2 月 12 日受理}

* $7720-0825$ 広島県福山市沖野上町 4-14-17

電話：084-922-0001 FAX：084-931-3969

E-mail : ostuka77jp@yahoo.co.jp
法の LC に比べて難易度が高いため, 適応は比較的炎症の 少ない胆石症や胆囊ポリープなどの胆囊良性疾患とした。 従来法との比較による手術成績の統計学的検討は 2010 年 1 月〜2012年 8 月までの 63 例を対象とし，比較検討には同時 期の LC 症例のうち, 急性胆襄炎及び慢性胆襄炎の急性増 悪例などの症例を除いた109例（以下 S-LC）を用いた。 2 群間の検定には $\chi^{2}$ 乗検定，及び $\mathrm{t}$-検定を用い, $\mathrm{p}<0.05$ を 持って有意差ありとした。この手術法には主にパラレル法 とクロスハンド法があり, 導入初期の 8 例は従来法のデバ イスのみで行え, 臍部 $2.5 \mathrm{~cm}$ の単一創から 3 本のトロッカー を挿入するマルチプルトラカールを用いたパラレル法で行 った22. マルチプルトラカール法はトラカール挿入がやや 繁雑であり, 新しいシングルポートデバイスの発売もあっ て, 9 例目からは臍部に $2.5 \mathrm{~cm}$ 切開を加えてシングルポート を挿入して，フレキシブル鉗子とストレート鉗子によるク ロスハンド法の一種であるコンバインド法尔を導入した。

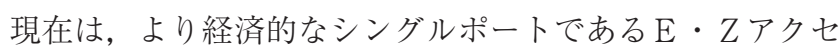
ス $^{\mathrm{TM}}$ （八光）を用いた方法にて全例施行しており，その方 
法について簡単に述べる。

\section{1 . 体位・配置}

体位は開脚仰臥位で, 術者は患者の左側, 第一助手は右 側, カメラ助手は脚間に立つ. カメラは $5 \mathrm{~mm}$ のフレシシブ ル腹腔鏡あるいは斜視の硬性鏡を用いた。

\section{2.アクセス法}

臍部を縦に $2.5 \mathrm{~cm}$ 切開してラッププロテクター ${ }^{\circledR}+\mathrm{E} ・$ Zアクセス ${ }^{\mathrm{TM}}$ (八光）を装着し, 正三角形の位置に $5 \mathrm{~mm}$ の $\mathrm{E} \cdot \mathrm{Z}$ トロッカーを 3 本挿入した（図 1 ).

\section{3 . 胆震の把持拳上}

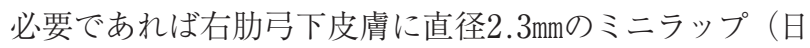
本ストライカー社)を直接穿刺して胆囊を把持して拳上した。

\section{4. 胆震剥離操作}

フレキシブル釷子とストレート鉗子によるクロスハンド 法の一種であるコンバインド法にて胆囊の剥離操作を行っ た 。フレキシブル針子は Roticulator endo grasp II（コヴ イディエン社）を使用した. 胆囊管, 胆囊動脈の処理は原 則 $5 \mathrm{~mm}$ のクリップを用いて行った。胆囊管が太くて $5 \mathrm{~mm}$ リップにて無理な時は $5 \mathrm{~mm}$ トローカーを $12 \mathrm{~mm} に$ 代えて $12 \mathrm{~mm}$ クリップにて行った。

\section{5 . 胆震回収. 創縫合}

$5 \mathrm{~mm}$ トロッカーを $12 \mathrm{~mm}$ に代えて回収バッグに入れて回収 した。腹膜筋膜は結節縫合して皮下埋没縫合した（図 1 ).
術中に胆汁污染がない限り,原則ドレーンは挿入していない.

\section{結果}

TANKO-LC は 2010 年 2 月に導入して 2012 年 8 月までに 63例経験した．当院での年次別症例数は 2009 年：LC 58例 (100\%), TANKO-LC 0 例 ( $0 \%), 2010$ 年：LC 62例 (78.5\%), TANKO-LC 17例（21.5\%)，2011年：LC 59例（66.2\%), TANKO-LC 30例 (33.8\%), 2012年 8 月まで：LC 24例 (53.3\%), TANKO-LC 21例 (46.7\%) と年々TANKO-LC の比率が上 昇している，患者背景は男性28例，女性35例，平均年齢は 53.7 歳. 対象疾患は胆囊結石症が56例と最多で, 胆囊腺筋 症 5 例，胆囊ポリープ 2 例であった。手術方法別に見ると マルチプルトラカール法 8 例, シングルポート法55例であ った。当初はマルチプルトラカール法にて行っていたが, 現在は全例， $\mathrm{E} ・ Z$ アクセス ${ }^{\mathrm{TM}}$ を用いたシングルポート法 にて行っている，手術成績を表 1 に示す，手術時間は70 158分，平均118分であった。トロッカー追加を 3 例に認め たが，2 例は手術操作が単孔式だけでは難しく操作性向上 のために，1例は助手の胆囊把持のためにそれぞれ $5 \mathrm{~mm}$ ポ 一トを 1 本追加した。術中胆囊穿孔は 4 例に認め, 全例洗 浄後ドレーンを留置したが, とくに術後合併症は認めなか った。術中術後合併症は 2 例に認め, 臍部の創感染であっ たが，全例保存的治療にて軽快した。全例翌日に経口摂取
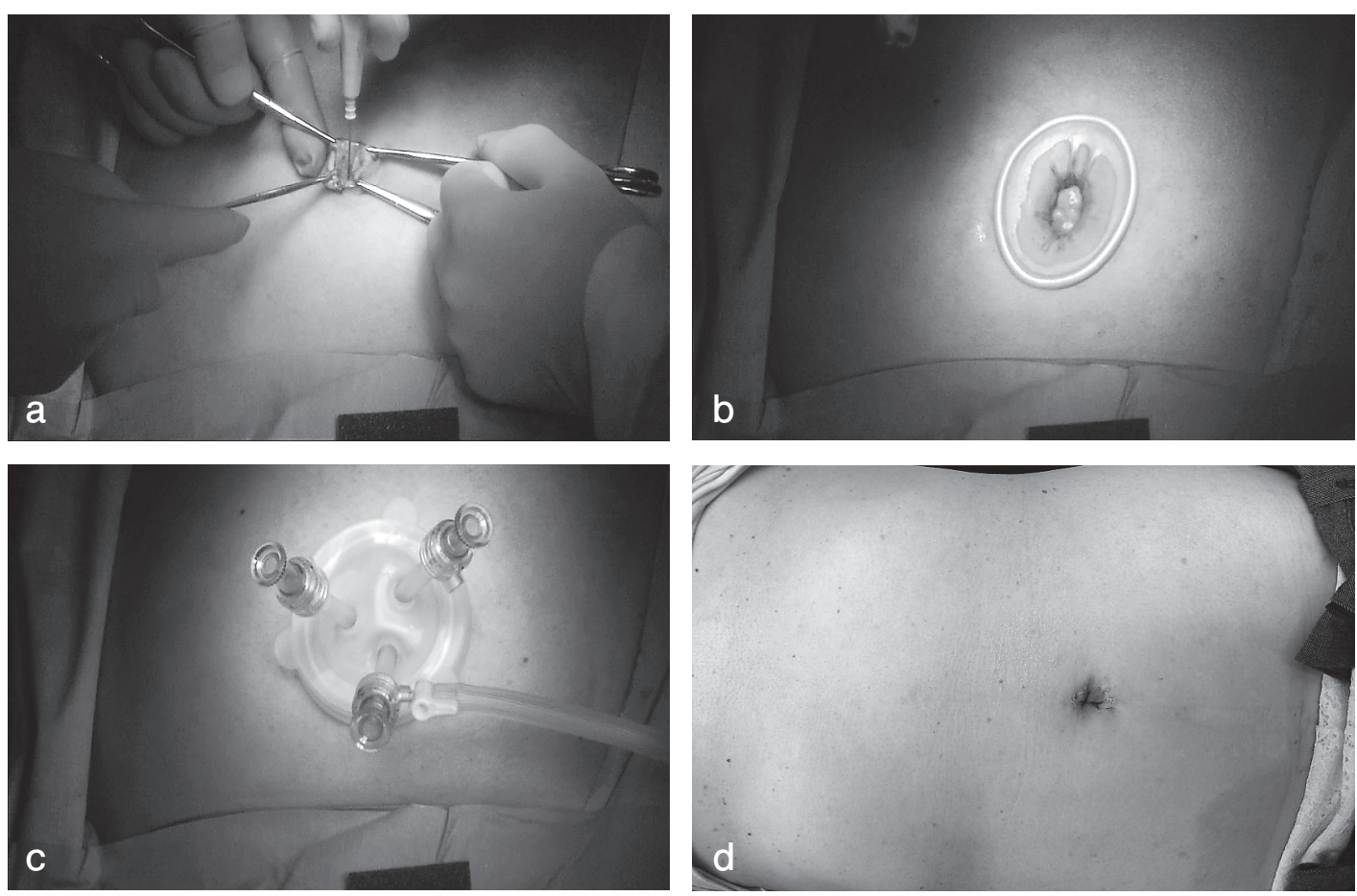

図 1 E・Zアクセスポート

$\mathrm{a}, \mathrm{b}, \mathrm{c}$ ：臍部に $2.5 \mathrm{~cm}$ 皮膚切開して，ラッププロテクター+ $\mathrm{E} \cdot \mathrm{Z}$ アクセス（八光）装着した. d：術後14日目創部。臍窩に隠れてほとんど不明であった. 
表 1 手術成績

\begin{tabular}{lccc}
\hline & $\begin{array}{c}\text { TNAKO-LC } \\
(\mathrm{n}=63)\end{array}$ & $\begin{array}{c}\text { LC } \\
(\mathrm{n}=109)\end{array}$ & $\mathrm{p}$-value \\
\hline 年齢 & $53.7 \pm 16.2$ & $65.9 \pm 13.7$ & 0.03 \\
性別 (男 : 女) & $28: 35$ & $54: 55$ & 0.52 \\
手術時間 (分) & $118 \pm 28$ & $90 \pm 36$ & $\mathrm{p}<0.001$ \\
出血量 $(\mathrm{cc})$ & $11.8 \pm 50.4$ & $8.7 \pm 30.2$ & 0.56 \\
トロッカー追加症例 & 3 & 0 & 0.023 \\
開腹移行症例 & 0 & 0 & 1 \\
術中胆賫穿孔例 & 4 & 4 & 0.44 \\
術中術後合併症 & 2 & 1 & 0.33 \\
術後在院日数 & $6.5 \pm 1.7$ & $8.2 \pm 3.1$ & $\mathrm{p}<0.001$ \\
\hline
\end{tabular}

開始し, 術後平均在院日数は6.5日であった。また, 2010年 1 月〜 2011年 8 月までの S-LC 109例と TANKO-LC 63例 にて手術成績の比較検討を行った，年齢は TANKO-LC 群 で有意に低かった。手術時間は TANKO-LC 群の方が有意 に長かったが, 出血量, 開腹移行率, 胆囊穿孔率, 合併症 に抏いては有意差を認めなかった。術後在院日数は $6.5 \pm$ 1.7日と有意に短い傾向にあった。

\section{考察}

1997年米国にて発表された単孔式腹腔鏡下手術は1)，本 邦でも当初は胆囊，虫垂などの良性疾患を中心として現在 は胃癌, 大腸癌にも普及してきている4). 当初思われてい た, 臍部を切開することの創部感染などのリスクも少なく, 従来の腹腔鏡手術と比較しても整容性の点でメリットがあ るためその適応は拡大傾向にある.臍部を $2.5 \sim 3 \mathrm{~cm}$ 皮膚切 開するが，術後は臍窩に隠れてほとんど目立たなくなり整 容性に優れる。アクセスポート作成法には大きくわけてシ ングルポート法年 とマルチプルトラカール法 ${ }^{2}$ があるが, 導 入当初は従来法の器具で行えるマルチプルトラカール法に て行っていたが，ポート挿入及び閉鎖の容易さ，気腹漏れ の少なさを考慮して現在はシングルポートを使用してい る.シングルポートとしては SILS ポートTM（コビディエ ン社）を使用していたが, 現在では経済性及び，よりポー 卜間の距離が取れて操作のし易い $\mathrm{E} \cdot \mathrm{Z}$ アクセスポートを 使用している。また，ミニラップ（日本ストライカー社） にて右肋弓下を直接穿刺して胆囊を把持したが，他のワイ ヤーなどを用いる方法に比べて把持力及び風性が増し，有 用であったまた，穿刺した皮膚創は $2 \mathrm{~mm}$ 程度で縫合も不 要で, 術後はほとんど目立たなくなった. 当初は平均120分 以上かかっていた手術時間もシングルポートの $\mathrm{E} \cdot \mathrm{Z}$ アク セスポートに変えてから，ラーニングカーブの影響もあり 100分前後に収まってきている.トロッカー追加を 3 例に認
めたが，2 例は炎症癒着のため手術操作が単孔式だけでは 難しく操作性向上のために，1例は胆囊が肥厚緊満してミ ニラップで把持できず助手の胆囊把持のためにそれぞれ 5 $\mathrm{mm}$ ポートを 1 本追加した。現在では, 胆囊緊満してミニラ ップで把持できない場合はポートを追加しないで，皮膚か ら直接胆囊を穿刺して胆汁液を吸引して把持を行うように している，ただ，安全に行うためにはトロッカー追加は躊 躇すべきでないものと思われた。開腹移行症例は認めてな いが，急性胆襄炎あるいは慢性胆襄炎の急性増悪例などは 対象にしていないためと思われた。術中術後合併症も臍部 の創部感染の 2 例だけであったが，全例保存的加療にて軽 快した。当初，思われていたほどの臍部を切開することに

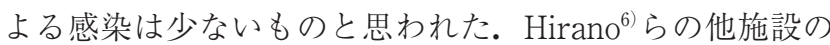
報告例でも術後合併症は 5 例 $(2 \%)$ と報告されているが, 肝損傷や胆汁漏，腸間膜損傷などの合併症も報告されてお り注意が必要である。炎症の少ない同時期の腹鏡下胆囊摘 出術との比較検討においても手術時間で長い傾向にあった が, 出血量, 開腹移行率, 胆囊穿孔率, 合併症に拀いても 有意差は認めなかった。同様の結果も多施設より報告され て㧈り ${ }^{7,8)}$, 手術の安全性と有用性が示唆された。但し，従 来法に比べて一カ所からの操作になるため術野の展開及び 操作においては問題点がある。術野の展開においては視軸 と操作軸がどうしても平行になってしまい，奥行きが見え ず，死角ができやすいという問題点があるが，フレキシブ ル腹腔鏡とフレキシブル鉗子を㧍互いに違う角度からアプ ローチ寸ることにより克服した，操作性においても井谷 $ら^{9)}$ の方法を参考に, 鉗子同士，鉗子と腹腔鏡との干渉を 防ぐために，適宜 3 本ある $5 \mathrm{~mm}$ ポートの場所を回転させて 操作性を向上させた。手術時間に関しては更なる技術の向 上にて短縮傾向にある，術後の創部痛については臍部皮下 をあまり剥離しないシングルポート法に変えてから少ない 傾向にあったが，従来法に比べて多いという報告例もあ $り^{10)}$ ，無駄な臍部皮下の剥離を行わないように注意が必要 である。

\section{結 論}

炎症の強くない症例に対しては単孔式腹腔鏡下胆囊摘出 術は従来法に比べてより整容性に優れ，手術合併症も有意 差なく，有用であった。特に $\mathrm{E} ・ \mathrm{Z}$ アクセスを用いたシン グルポート法は簡便で操作も比較的容易であった。但し, 従来法の腹腔鏡下胆囊摘出術に比べると技術的には高いも のが求められ，更なる技術の向上と術中トラブル発生時は トロッカーの追加などの処置をためらわずに行うべきもの と思われた。 


\section{文献}

1) Navarra G, Pozza E, Occhionorelli S, Carcoforo P, Donini I : One-wound laparoscopic cholecystectomy. Br J Surg (1997) 84, 695.

2 ）北城秀司, 奥芝俊一, 川原田陽, 七戸俊明, 海老原裕磨, 佐々木 剛志, 加藤絃之 : マルチプルトロカール法による単孔式腹腔鏡下 胆囊摘出術 パラレル法. 手術 (2011) 65, 23-27.

3 ) 河合 徹, 小倉 豊, 白井 量, 徳丸勝吾, 相場利貞, 片山 信 : 単孔式腹腔鏡下胆囊摘出術46例の経験。日鏡外会誌 (2011) 16 , 187-194.

4 ) 山形基夫, 松田 年, 高山忠利：消化器外科セミナー 単孔式内 視鏡手術の概念と現況. 消化器外科 (2010) 33，1355-1363.

5 ）鈴木憲次, 奥村拓也, 岡本和哉：シングルポートを用いた単孔式 腹腔鏡下胆囊摘出術. 手術 (2011) 65, 29-34.

6 ) Hirano Y, Watanabe T, Uchida T, Yoshida S, Tawaraya K,
Kato H, Hosokawa O: Single-incision laparoscopic cholecystectomy: single institution experience and literature review. World J Gastroenterol (2010) 16, 270-274.

7 ) 円城寺恩, 榎本直紀, 大槻 将, 上田吉弘, 加藤俊介, 大野 玲 : 単孔式腹腔鏡下胆囊摘出術の初期成績 一腹腔鏡下胆囊摘出術と 比較して。外科 (2011) 73，530-532.

8 ) 伊藤康博：当施設における単孔式腹腔鏡下胆囊摘出術の検討. 胆 道 (2011) 25, 626-629.

9 ) 井谷史嗣, 浅海伸也, 中野敢友, 熊野健二郎, 野島洋樹, 高倉範 尚：単孔式胆囊摘出術における critical view 描出のための工夫 Hook and Roll technique. 手術 (2010) 64, 1661-1666.

10）野島広之, 吉富秀幸, 細川 勇, 木村文夫, 清水宏明, 宮崎 勝 : 単孔式腹腔鏡下胆囊摘出術における工夫 従来法との比較. 臨床 外科（2011）66，1551-1554. 